\title{
Mixed reaction to New Zealand reforms
}

[SYDNEY] A wide-ranging overhaul of university funding in New Zealand, announced last month in a long-delayed white paper on tertiary education, has pleased polytechnics and government-owned Crown Research Institutes, but attracted criticism from university leaders and researchers.

Wyatt Creech, the education minister and deputy prime minister in the National Party minority government, has watered down some controversial proposals from the 1997 green paper, such as turning universities into government-owned corporations (see Nature 392, 320; 1998).

Statutory independence is retained, although governing councils will be halved to a maximum of 12 members, with minimal academic representation and government "intervention" for "high-risk institutions".

Creech will retain overall financial control, but substantial funding will be shifted from universities to polytechnics and the growing number of Private Tertiary Establishments, including those from overseas.

Tony Steel, the National Party's chair of the parliamentary education and science committee, told last week's Association of University Staff conference that New Zealand has too many universities, and research funds "were going to some arts disciplines where it was questionable that the outcomes justified the cost".

There will be more research programmes for polytechnic staff to ensure greater equity across sectors. A quality assurance authority will be set up, with funding being contingent on quality in teaching and research.

The Association of Polytechnics described the white paper as "positive, constructive and sensible". Jim Doyle, the association's executive director, says a polytechnic student presently has access to assets of just NZ\$14,000 (US\$7,300), compared with NZ\$29,000 for a university student.

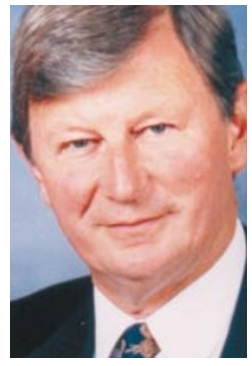

There are 57,237 equivalent full-time students in 25 polytechnics and 83,528 in seven universities, receiving subsidies of NZ\$402 million and NZ\$684 million, respectively. "Tuition subsidies will be provided on the same Gould: Among those basis, no matter where critical of changes. they [the students] are studying", says Creech.

The 34,000 students in private tertiary establishments will become eligible for subsidies.

From an estimated NZ\$100 million for postgraduate training in universities, a "contestable pool" of NZ\$20 million will be established for "targeted programmes" (allowing the government to direct research). The remaining NZ\$80 million will go to institutions through top-ups of tuition subsidies to degrees and postgraduate programmes.

Creech promised that funding and legislative requirements for research will be reviewed in 2001 "with a view to transferring a further NZ\$60 million to the contestable pool".

Despite the watering down, the changes have still been criticized by senior university officials. Daryl Le Grew, vice-chancellor of the University of Canterbury, fears the effect on "a top-end research university". He predicts a legal challenge over "institutional ownership", and attacks the plan for "seeking the safety of mediocrity".

Alastair MacCormick, acting vice-chancellor of the University of Auckland, sees "threats to institutional autonomy and therefore academic freedom". This is echoed by Jane Kelsey, president-elect of the Association of University Staff, who is concerned that the changes "will take money away from the libraries, technology and staff”.

\section{UK minister says sorry for science past}

[LONDON] The 'shadow' science minister in Britain's opposition Conservative party has expressed regret for cuts to science funding while the Conservatives were in power.

In a speech last week to the pressure group Save British Science, John Redwood, the opposition spokesman for trade and industry, said he welcomed the current government's increase in the science budget (see Nature 394, 209; 1998).

But Redwood conceded that the previous Conservative government had not left science in as good a state as it should have done. "We accept we have made mistakes in the past. We have changed," he said. New Conservative science policies would emphasize factors such as the need to provide generous tax incentives for investment in research by private investors.

Redwood added that the Conservative party was attempting to learn from its mistakes following its disastrous failure in the last election, and was listening directly to public opinion about its policies.

He also criticized the government for "dressing up" the value of the increase in spending on science. Under the terms of the comprehensive spending review a further $\mathfrak{E 7 0 0}$ million (US\$1,157 million) will go to science. But the 15 per cent real terms increase over 1998-99 baseline funding will be spread over three years. Natasha Loder
Bryan Gould, vice-chancellor of Waikato University and chairman of the NZ ViceChancellors' Committee, describes the creation of the quality assurance authority as "unnecessarily heavy-handed and otiose". He says it is being set up "not because of any perceived deficiencies in the universities' own quality assurance procedures, but because of a [political] need to establish uniformity across the sector".

The committee says the transfer from universities will cut funding for their postgraduate research programmes by NZ\$7.5 million a year. There is also scepticism about extra long-term funding after Maurice Williamson, the science minister, berated scientists for drawing attention to his recent retreat from a 1996 commitment to boost gross expenditure on R\&D from 0.5 per cent of gross domestic product to 0.8 per cent by 2010 .

Universities claim that the 'portability' of subsidies will add uncertainty to course planning, staffing and allocation of infrastructure. The white paper says the changes will improve research quality, a claim disputed by Gould, who says "it is hard to imagine a more damaging recipe for destroying the New Zealand research effort".

He describes as a "hammer blow" to universities a "capital charge" of reducing tuition subsidies for students attending "asset-rich" universities, with the saving being passed to "poorer" institutions.

The Association of Crown Research Institutes has been campaigning against what it sees as an unfair allocation of funding to universities (see Nature 391, 834; 1998), as the institutes have had to cut staff this year. Ian Warrington, the association's president, welcomes the government's "forcing a reassessment of research qualities within existing tertiary institutions".

Warrington suggests that "a blurring of the use of funds within universities" will be mitigated by contestability. But Kelsey predicts that the increase in contestable research funding - and decrease in non-contestable funding - would "result in those who taught being alienated from doing research".

George Petersen, a biochemist at Otago University and president of the academy of the Royal Society of New Zealand, speaking in a personal capacity, believes the policies will result in "a large number of poorly funded institutions, a curious way of going about the improvement of tertiary educational quality". He attacks Creech for giving no details of how the research fund will be administered.

In contrast, John Campbell, a physicist at the University of Canterbury and prominent promoter of science, argues that universities "are getting what they deserve for past arrogance and aloofness".

PeterPockley 